\title{
Transmission of alpha-synuclein in Parkinson's disease
}

\author{
Virginia M-Y Lee \\ From Molecular Neurodegeneration: Basic biology and disease pathways \\ Cannes, France. 10-12 September 2013
}

The accumulation of misfolded proteins is a fundamental pathogenic process in neurodegenerative diseases. However, the factors that trigger aggregation and spreading of $\alpha$-synuclein ( $\alpha$-syn), the principal component of the intraneuronal inclusions known as Lewy bodies (LBs) and Lewy neurites (LNs) that characterize Parkinson's disease (PD) and dementia with LBs (DLB) in brain are poorly understood. We demonstrate that pre-formed fibrils (pffs) generated from recombinant $\alpha$-syn enter cultured primary neurons generated from non-transgenic wildtype mice, promote recruitment of soluble endogenous $\alpha$-syn into insoluble PD-like LBs and LNs. Accumulation of pathologic $\alpha$-syn led to selective decreases in synaptic proteins, progressive impairments in neuronal excitability and connectivity, and eventually, neuron death. Moreover, we further show that in young asymptomatic $\alpha$-syn transgenic ( $\mathrm{Tg}$ ) mice, intracerebral injections of synthetic $\alpha$-syn pffs accelerate both the formation of intracellular LB/LN-like inclusions and the onset of neurological symptoms in recipient animals. Pathologic $\alpha$-syn propagated along major central nervous system (CNS) pathways to regions far beyond injection sites and dramatically reduced survival with a highly reproducible interval from injection to death in inoculated animals. Thus, synthetic $\alpha$-Syn pffs are wholly sufficient to initiate PD-like LBs/LNs and to transmit disease in primary neurons in vitro and $\mathrm{Tg}$ mice in vivo. Thus, these data support a prion-like cascade in synucleinopathies whereby cell-to-cell transmission and propagation of misfolded $\alpha$-syn underlie the CNS proliferation of LBs/LNs. These findings open up new avenues for understanding the progression of PD and for developing novel therapeutics.

University of Pennsylvania, USA

@ 2013 Lee; licensee BioMed Central Ltd. This is an Open Access article distributed under the terms of the Creative Commons
Published: 13 September 2013

doi:10.1186/1750-1326-8-S1-025

Cite this article as: Lee: Transmission of alpha-synuclein in

Parkinson's disease. Molecular Neurodegeneration 2013 8(Suppl 1):O25. and take full advantage of:

- Convenient online submission

- Thorough peer review

- No space constraints or color figure charges

- Immediate publication on acceptance

- Inclusion in PubMed, CAS, Scopus and Google Scholar

- Research which is freely available for redistribution 